\title{
Nietzsche on Sickness and Health
}

\author{
Lawrence J. Hatab ${ }^{1}$
}

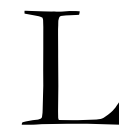

iving in the time of a pandemic, where illness has become a prominent concern, it might do well to consider Nietzsche's thinking on sickness and health, which is far from a clear-cut delineation and calls for careful and circumspect analysis. I begin by distinguishing three types of sickness and health: physical, psychological, and cultural, where health in each type can initially be understood as flourishing unimpaired by sickness. Physical illness involves some infirmity of the body, such as cancer or viral infection. Psychological illness is some malady of the mind, such as depression. Cultural illness is the kind of thing emphasized by Nietzsche and involves a worldview that is symptomatic of life denial and nihilism when measured against natural life instincts, energies, and needsfor instance, the story Nietzsche tells about slave morality and its production of the ascetic ideal that has contaminated Western thought.

It seems easy enough to understand sickness and health under physical and psychological descriptions - as suffering from afflictions of body and mind, being relieved of them, or enjoying well-functioning physical and mental powers. Cultural health and sickness appear to be clearly distinguished in Nietzsche's account of master and slave morality respectively. But it should be no surprise that the matters at hand in his philosophy are complex and ambiguous. Indeed, sickness and health resist "definition" because they are relative to individual cases, where the health in one case can be sickness in another, and vice versa (GS 120). I will explore this issue by asking whether sickness and health in any of the three categories are always a binary manner, whether sickness can be productive in certain ways or even a prelude to health in some manner. It all depends on what is meant by sickness and health, especially in the cultural category, and Nietzsche's thinking on this score is not always easy to get right. To begin, I select a few instances that illustrate the complexity of his position on the furtherance and decline of cultural life.

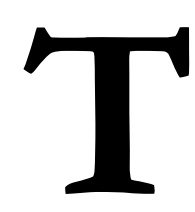

\section{he Ambiguity of Human Sickness and Health}

The kind of cultural sickness and health emphasized by Nietzsche might correlate with physical and psychological categories, but the cultural type is informed by symbolic registers of meaning beyond individual infirmities of body and mind. According to Nietzsche's genealogical script, cultural sickness began with slave morality and its revolt against the natural life forces of master morality, where healthy assertive instincts and achievements were judged to be evil by those who suffered at the hands of noble types. The Judeo-Christian tradition carried the banner of

${ }^{1}$ Lawrence J. Hatab, Old Dominion University, Norfolk, Virginia, United States. E-mail: lhatab@odu.edu. 
slave morality and was perfected in the ascetic ideal of self-inflicted life denial—exhibited not only in religious renunciation but also rationalistic and scientific regimes of secured truth (GM III, 12-25). In any case, slave and master morality seem to be clear instances of cultural sickness and health.

Nietzsche's genealogical narrative offers a natural history of cultural illness that begins with a focus on animal life and matters of memory and forgetting. In both On the Uses and Abuses of History for Life (1) and the Genealogy (II, 1-2) there is a baseline of animal health and happiness grounded in the ability to forget and threatened by the power of memory. Nonhuman animals live in the present without a sense of time and history, without memories of the past or anticipations of the future. Accordingly, animals are happy; they neither dwell on misfortunes nor worry about coming troubles. Human health depends on "active forgetting," which means letting go a fixation on past tribulations in favor of new possibilities for a productive future. Memory therefore can infect natural health by keeping misfortunes in mind and cultivating slavish and ascetic sensibilities, which amount to a life-preserving worldview for those who are fixated on suffering.

In GM III, 13, Nietzsche associates the ascetic ideal's life-preserving power with human "sickliness" (Krankhaftigkeit). At first there seems to be a clear indication here of a critical posture against "degenerating life." Indeed, the historical success of the ascetic ideal is called proof that the prevailing model for human existence "up until now" has been a symptom of sickness and alienation from natural life. Yet this polemic is not without ambiguity. The power of asceticism provides life-sustaining meaning for a "sick animal." In fact, we are told, mankind is the sick animal compared with all other species. The implication is that animal life is normally a more natural health and that the human animal develops a kind of natural illness. Then Nietzsche asks: What causes this sickness? Here is where things get complicated.

Nietzsche begins by correlating, even identifying, human sickness with something valorous: Humans are sicker in being more uncertain and changeable; also in being unfestgestellter, which can be translated in several ways-as more undetermined, indeterminate, unsecured, unestablished, or unrealized. Given Nietzsche's preference for conditions of becoming, such characterizations can hardly be problematic in principle. Indeed, Nietzsche connects human sickness with seemingly admirable qualities:

He is the sick animal: where does this come from? Certainly he has dared more, innovated more, braved more, and has challenged fate more than all the rest of the animals taken together: he, the great experimenter with himself . . . .

Nietzsche then calls humankind the "eternal-futurist," whose strength (Kraft) is an unstoppable urge to the future that "inexorably digs into the flesh of every present like a spur." Right away Nietzsche adds: "How could such a courageous and rich animal not also be the most endangered, the most profoundly and extensively sick of all the sick animals?"

What are we to make of this intricate mix of characterizations, especially when it includes elements that seem to accord with Nietzschean virtues (daring, innovation, experimentation)? I think the reference to the future and its "injury" to the present gives us a clue. The temporality of experience seems to dictate the courage that elevates humans over other animals. Surely animals are in time, but humans seem to be aware of time in a 
special way. Animal life is more immersed in the immediacy of present circumstances and instinctive behavior. For humans, the "non-being" of the future and the past have a presence, as shown in our capacity to anticipate and recall events that are not yet or no longer present. The ability to perceive otherwise than the present accounts for human innovation and experimentation, but it also calls for an abiding courage to withstand the continuing force of negation entailed by temporal awareness. Human experimentation also carries a comprehension of the possibility of failure, and so our projects can be haunted by finitude in a way that instinctive behavior is not. More generally, the awareness of death in the midst of life_-even without any present threat_-gives human existence a special burden. The condition of animals is also mortal and thus tragic in the end, but humans are conscious of tragic mortality, even at times of safety and success, and so they can incorporate a tragic awareness into their very sense of life, for better or worse.

I believe that such an orientation on temporality explains why Nietzsche combines bravery, endangerment, and sickness in his account of human existence. Unlike other animals, humans are "set loose" from the instinctive immediacy of brute nature by "exceeding" the present in a perception of past and future conditions-the creative potential in this excess recalls a remark earlier in the text $(G M I I, 19)$ that bad conscience is a sickness in the manner of pregnancy. Yet temporal experience in this way is infused by negations of present "being," and so the human animal is marked by an intrinsic insecurity that registers at every level of life. For humans, becoming is not just a fact of nature, it is also a tragic burden pressed upon our experiences and sense of meaning.

Perhaps we can summarize Nietzsche's analysis in the following manner: Humans are first and foremost embedded in the first nature of animal life. The second nature of temporal experience engenders both the greater capacities of the human animal and the burden of tragic awareness. This burden can engender life-denying dispositions and worldviews, which no animal would exhibit; but it can also engender self-awareness of the danger of life-denial and its possible overcoming. The temporal injury to the present-centered contentment of animal life is also the precondition for what most distinguishes the human species, creative departures from "being" toward novel possibilities — in everything from the creation of slave morality to Nietzsche's ideal of the free spirit, one who redeems the tragic burden of existence with life-affirming energies and new horizons of value. The point is that "sickness" and "health" are ambiguous in Nietzsche's account. There is the primal health of animal happiness which is lost in the primal sickness of temporal awareness. Then there is the secondary and contingent sickness of life-denying values, which can be overcome by the secondary health of life-affirming creativity, which is not a return to animal happiness but an affirmative appropriation of the human burden of tragic consciousness. As Nietzsche put it in WS 350: Moral and religious chains have caused humans to forget their animal nature. Such chains cause a sickness that once removed is not a relapse into animality but a "separation" (Abtrennung) from animals toward the possibility of free-spiritedness.

\footnotetext{
Whe Ambiguity of Nietzsche's Genealogy

A careful reading of Nietzsche's texts does not support the thesis that his genealogy of master and slave morality is exclusively a defense of robust health, crude physical power, or overt social control. Throughout the writings, the
} 


\section{Nietzsche on Sickness and Health}

meaning of weakness, strength, power, sickness, and health is polymorphous and far from clear. For instance, Nietzsche calls the values he criticizes necessary for life. Morality has been essential for human development in its contest with nature and natural drives (KS $A$ 12: 5 [63]), and for this it deserves gratitude (KSA 12: 5 [58]). The exceptional individual is not the only object of honor for Nietzsche; conditions of the rule are equally important for the species (GS 55). The "weakness" of the slave/herd mentality turns out to be a practical advantage, since it has succeeded in supplanting the strong: "The weak prevail over the strong again and again, for they are the great majority-and they are also more intelligent" (TI Skirmishes, 14). Indeed, the higher types of creative individuals that Nietzsche favors are more vulnerable and perish more easily because of their complexity, in contrast to the simplified order of herd conditions (BGE 62).

Master morality is clearly an instance of worldly power, but not the only kind. Will to power in general terms is connected with creativity, with "spontaneous, aggressive, expansive, form-giving forces that give new interpretations and directions" (GM II,12). The slave's external circumstance is constrained by the strength of the master, but the slave mentality can exercise will to power in the inner domain of imagination.

All instincts that do not discharge themselves outwardly turn inward - this is what I call the internalization (Verinnerlichung) of man: thus it was that man first developed what was later called his "soul." The entire inner world, originally as thin as if it were stretched between two membranes, expanded and extended itself, acquired depth, breadth, and height, in the same measure as outward discharge was inhibited. (GM II,16)

In fact, the slave mentality is the prerequisite for spiritual cultivation (BGE 188); the "weak" represent a positive power of spirit (TI Skirmishes,14) because their resentment of the strong opens up the possibilities of a refined culture, which is based on der Vergeistigung und Vertiefung der Grausamkeit, "the spiritualization and deepening of cruelty" (BGE 229). Such a turn begins to make mankind "an interesting animal," because the most ancient cultural concepts were "incredibly uncouth, coarse, external, narrow, straightforward, and altogether unsymbolical in meaning" (GM I,6). Now higher culture is possible, since "human history would be altogether too stupid a thing without the spirit that the impotent have introduced into it" (GM I,7). So, the master-slave distinction may have clear delineations at first, but it begins to get complicated in the context of cultural creativity and Nietzsche's brand of higher types.

In GM I, 16, Nietzsche declares an ambiguity in the master-slave opposition. Beyond the historical examples of noble morality examined in the text, he says something that notably is put in the present tense: Despite the historical victory of slave morality and its enduring power over master morality,

There is still no lack of places where the battle remains undecided. One might even say that meanwhile it has been raised ever higher and because of this it has become ever more profound and more spiritual (geistiger): so that there is today perhaps no more decisive mark of the "higher nature," the spiritual nature, than to be divided in this sense and actually be another battleground for these opposites. 
This significant passage can be compared with a remark in Beyond Good and Evil 260, where Nietzsche first introduced the opposition between master and slave morality. Before he begins to describe the two standpoints, he interjects:

I add immediately that in all higher and mixed cultures attempts to mediate between the two moralities also appear, yet more often a confusion and mutual misunderstanding of the two, indeed on occasion their severe, difficult coexistence (Nebeneinander) — even in the same person, within a single soul.

Such remarks are crucial provisos for coming to understand the meaning and scope of Nietzsche's genealogy. The conflict between master and slave morality is not exclusively a matter of two discrete cultural camps, one representing strength and health, the other weakness and sickness. The conflict can be mediated within a culture and even within a single self. Such mediation further ambiguates the meaning of the evaluative terms involved.

\section{The Ambiguity of Degeneration}

One must concede that at times Nietzsche advances what seems to be an unambiguous delineation of sick and healthy types, with the former representing a blight on life that should be excised. This is especially the case when diagnosing decadence and degeneration. Christianity, we are told, is a form of decadence, the rancor of the sick against anything healthy, well-constituted, highspirited, and beautiful $(A 17,51)$. The sick and degenerate are parasites on society; on behalf of ascending life they should be "ruthlessly pushed down and thrown aside," and denied the right to live and procreate (TI Skirmishes, 36). It is hard to stomach such things, especially if one wants to generally recommend Nietzsche's philosophy. One hopes that the ambiguities we have noted are an antidote to such disturbing moments in the texts.

In the case of degeneracy, complications can be noted, especially when Nietzsche seems to connect creativity with degeneration when measured against social norms. In HH 224 (a section titled Ennoblement through Degeneration), Nietzsche discusses the preserving "strength" of social custom counterposed against "morally weaker individuals" who cannot or will not fit in with social norms and capacities. Yet such individuals, precisely because they do not fit in, can discover new pathways and effect "spiritual progress." Nietzsche is here suggesting that the possibility of innovation stems from misfits, who from the standpoint of social cohesion must be perceived as weak or degenerate. I submit that throughout his texts, Nietzsche analyzes weakness and strength, sickness and health, from various perspectives and shows their shifting virtues and tensions. In this passage from $\mathrm{HH}$, Nietzsche highlights the intrinsic tension of necessary forces in human life that promote both stability and novelty. The cohesion of "strong communities" faces the danger of a "gradually increasing inherited stupidity such as haunts all stability like its shadow." Individuals who are weak by social standards may bring forth new horizons, but it is also true that "countless numbers of this type perish on account of their weakness without producing any very visible effect." Yet when such types can discover something new, their "social degeneracy" corrects for the stupidity of "social strength."

Degenerate natures are of the highest significance wherever progress is to be effected. Every progress of the whole has to be preceded by a partial weakening. 
The strongest natures preserve the type, the weaker help it to evolve. . . The more sickly man, for example, will if he belongs to a war-like and restless race perhaps have more inducement to stay by himself and thereby acquire more repose and wisdom . . . . To this extent the celebrated struggle for existence does not seem to me to be the only theory by which the progress or strengthening of a man or a race can be explained. Two things, rather, must come together: first the augmentation of the stabilizing force through the union of minds in belief and communal feeling; then the possibility of the attainment of higher goals through the occurrence of degenerate natures, and, as a consequence of them, partial weakenings and injurings of the stabilizing force; it is precisely the weaker nature, as the tenderer and more refined, that makes any progress possible at all.

Material such as this must be kept in mind when considering Nietzsche's complicated and ambiguous analysis of weakness and strength, sickness and health. In the Genealogy, the trope of sickness and health is usually tied to the debilitating capacity of social norms in slave morality measured against the natural strength and vitality of master types. Yet we have seen that weakness or sickness can exhibit productive strength when it comes to innovation. What matters is whether strength or weakness is understood from the perspective of social regulation or social transgression. Regulation is a cohesive strength, for which transgression is a weakness. Yet transgression (whether in master morality or innovative movement) is a life-advancing strength, for which cohesion is a weakness. Such perspectival ambiguity must be recognized if the course of Nietzsche's thinking is to be fathomed well. I should add that Nietzsche recognized such ambiguity in his own life. In EH Wise, 2, he admits to being a decadent, but its opposite as well. He speaks of a "basic health" that allows him a productive recovery from sickness, which requires that he "knows how to forget" - an echo of the active forgetting that does not dwell on misfortune. In any case, creators need a "great health" that is continually acquired and given up (EH Books Z, 2)—which implies a cyclic alternation of sickness and health rather than an ideal of unadulterated health, something Nietzsche calls "cowardice" and a "most refined barbarism" (GS 120).

\section{W}

hat Do Sickness and Health Mean?

In an attempt to sort out the complexities in Nietzsche's thinking on these matters, I suggest reserving the term "illness" for the physical and psychological categories, and "sickness" for the cultural category, which is the type that most occupies Nietzsche. Yet the texts at times adopt a "physiological" orientation (BGE 26, 202, 242, for instance). This raises a question: Is cultural sickness a consequence of, or accompanied by, physical or psychological illness? Put the other way: Is cultural health a consequence of, or accompanied by, physical or psychological health? An answer to the latter question in the affirmative would seem to follow from crude racist visions of cultural/ national health threatened by degenerate types. But that cannot well fit Nietzsche's approach, not only because of his objections to nationalism and anti-Semitism, but also the ambiguities in his treatments of sickness and health, weakness and strength, and productive degeneracy. 
Compared to animal health, we may need to posit a distinct malady, namely the natural sickness of the human condition, the burden of tragic temporality-call it constitutional sickness. As a result of this sickness, cultural creativity is a matter of meaning-making in the midst of finitude, which in its life-sustaining function should be recognized as a kind of health. Yet Nietzsche's calling is to diagnose cultural sickness and health, according to whether meaning-making stems from a denial or affirmation of natural life. As we saw in the case of productive degeneracy, physical or psychological illness can be a factor in the generation of cultural creativity, but the main concern for Nietzsche is the life-evaluative posture of a created world-view. For a long time, I have argued that we need to distinguish between life-enhancement and life-affirmation. The former applies to meaning-making that serves the needs of human types that cannot abide natural finitude (for instance, slave morality and Christianity), while the latter is Nietzsche's specific interest in affirming natural life as it is, with all its positive and negative elements together, with no alternative (captured in the teaching of eternal recurrence).

This leads to speculation on my part: Human beings by nature are constitutionally sick. Meaning-making is a life-enhancing creation that could be called a kind of healthy response to constitutional sickness. Cultural creativity issues from unusual individuals who may be degenerate (measured by social norms) and who may fail or perish accordingly, but who may produce new orientations for human life. Successful creators have their own specific "health" in terms of a surplus of energy that overflows into productive novelty. Nietzsche often talks about such energy-overflow in creative types (GS 354, BGE 213, Z I, The GiftGiving Virtue). It should be noted that slave morality (as a world-view) was not fashioned by ordinary dependents themselves, but by the creative vision of the priest type (GM I, 69 , II, 18). Innovative individuals by nature may suffer from a dis-ease, from being ill at ease with their world as it is; and then being prone to a "perilous curiosity" about different possibilities (HH P, 3). The underlying "health" of such innovative types can be measured by their creative energy, even though they may be "sick" or "weak" by extant standards. What ultimately matters to Nietzsche is whether culture-creation retains, or is constituted by, a sickly rancor toward the world. Zarathustra himself suffered from contempt toward humanity and especially the "small man." But the measure of eternal recurrence was the avenue for Zarathustra's eventual overcoming of rancor and his achievement of life affirmation. In sum, with these reflections I have tried to navigate and sort out the complex convolutions in Nietzsche's approach to sickness and health.

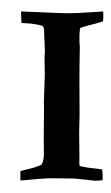

\section{llness and Affirmation}

It would seem that life-affirmation, for Nietzsche, would represent the highest kind of health; yet its relation to physical and psychological illness is a difficult question, since such maladies could easily be an impediment to embracing existence. But Nietzsche sees no dissonance here. A sickly person not only can have a greater appreciation of health, but also more attunement to how illness and health figure in human projects (MOM 356). Indeed, being relieved of the difficulties of life may impair vital instincts that are excited in times of trouble. In GS 48, Nietzsche recommends that we experience more distress (Not), that pessimism is more likely in comfortable times-when slight "mosquito bites of the soul and body" are felt to be deeply injurious. With less real experience of pain, even painful ideas cause great suffering. Life-affirmation is nothing comfortable. Zarathustra needed to experience distress over the recurrence of the small man 
(Z II, Soothsayer), because saying Yes to life in its entirety would include what he most opposes - thus a "turning of all distress" (Wende aller Not) that embraces the necessity (Notwendigkeit) of all things (Z I, Gift-Giving Virtue, 1).

Zarathustra claims that belief in some reality beyond the natural world stems from a sickness, and that we should listen to the "healthy body" that expresses the meaning of the earth (Z I, Hinterworld). Behind the ego lies the body-self, which does not "speak" I but does I-an enactive self expressing a wisdom that is deeper than conscious knowledge (Z I, Despisers of the Body). The healthy body is a creative will, which overcomes a degenerate, sick body that bespeaks a selfish covetousness. The gift-giving body can heal itself by creative acts for the betterment of human life. Nietzsche's attention to the body, healing, and creative work stems from his own experience of rejuvenation through writing after periods of pronounced illness (specifically expressed in GS). He never separated intellectual activity from an acute sense of embodiment.

Nietzsche's ideal of affirming life is all the more impressive given the severe difficulties he faced with his health problems and mental deterioration. He suffered periodically from acute depression, his eyesight slowly declined to near blindness, he regularly had intense bouts of migraine headaches and attacks of vomiting. He rarely had stretches of good health. In early 1889, he had a mental collapse, triggered by an episode involving a wagon horse being beaten by its owner. Nietzsche threw his arms around the animal, sobbing, and he fell to the ground in a fit. He lived the final 10 years of his life eclipsed by insanity, and he had to be cared for by his mother and sister. There is a report from a witness to one of his days in this condition, which shows the heartbreaking tragedy visited upon one of the most creative and penetrating thinkers in modern times: Nietzsche's mother brought him along when she visited the house of a friend. He followed her like a child. Before she sat with the other guests, she took him to a drawing room, where he first loitered by the door. She walked to a piano there and played a few chords, and he inched closer. Then he began to play himself, first while standing, until his mother pressed him down on the stool. Her son then improvised for hours while his mother visited in another room. She knew he was all right and did not need to be watched, as long as she could hear him playing. The quiet calamity of Nietzsche's final years depicted here is hard to bear, yet the passion for life expressed in his writings can still shine despite all his sufferings.

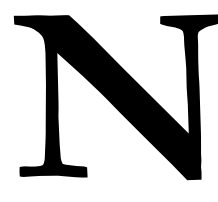

\section{ietzsche in My Life}

As I have written in Nietzsche's Life Sentence, my own illness has figured in my attraction to Nietzsche's philosophy. I have suffered from depression since my early days, and my experience is anything but a joyous affirmation of life. Probably because of my condition, I was from the start summoned by Nietzsche's writings not to interpret life through the lens of my own psychological infirmity, and to suffer a little less because of Nietzsche's acute concentration on coming to terms with existence as it is - also to heartily appreciate anyone else's joy in life, perhaps more than they do. I also became attuned to Nietzsche's idea that the body knows more than the conscious ego does. In 2018, I came down with leukemia, and the only hope was a bone marrow transplant, a difficult treatment that I endured in 2019. Complications had me in a coma for two months and the survival rate in my condition was $12 \%$. At one point they thought I was brain-dead, but a neurological scan showed a still healthy brain 
function, much to the surprise of the neurosurgeon. My wife told him that I had been reading and writing philosophy for 50 years. He said, "that's probably it." When I recovered, I had no sense of the time I was unconscious. I realized then that my body was stronger than I was; it wanted to live more than I did. Ever since then I have experienced a certain calm that comes from omitting my conscious self from the assessment ledger. I survived and have been living on borrowed time, thanks to my physiology. I may not possess what Nietzsche called "a joyous and trusting fatalism" (TI Skirmishes, 49), but at least I can call it trusting.

\section{A}

\section{Viral Naturalism}

Nietzsche is often taken to be a naturalist, usually in the current sense of relying on natural science for a proper understanding of reality. Although Nietzsche certainly affirmed the value of scientific thinking, he just as surely rejected a scientistic reduction of knowledge to the findings of science. In assuming "natural life" as his philosophical focus, Nietzsche insisted that the unruly, injurious, and haphazard aspects of natural events and animal drives should be incorporated in philosophical thinking. Human interests and comprehension are not always honored in the world we live in. For Nietzsche, turning to nature is also something "terrible" (BGE 230), something "indifferent without measure, without purpose and regard, without mercy and justice" (BGE 9).

With all the concerns and tribulations caused by the current pandemic, we have to remember that viruses are a part of nature; they may even have been implicated in the first forms of cellular life. But they are parasitic on life forms and instigate a struggle for survival that is one more illustration of will to power in Nietzsche's terms. In the larger scheme of things, viruses are no less entitled to assert themselves (I recall a cartoon years ago where a medical researcher sees in a microscope a line of placards declaring "viruses have rights, too"). Even as we fight back against the covid virus, it should teach us humility about our place in nature. We should be more attuned to the fragility of human life along with the blessings of health. Nothing of value is secure or guaranteed; we are not at the center of things. I have long argued that Nietzsche's concept of the Übermensch is not the prospect of some higher type of existence, but rather his own "Copernican revolution" calling us to get "over" our human-centered perspective on life. With all the assertions of our interests, a genuine affirmation of life must accommodate the larger economy of forces that envelop our dwelling on earth. To be "faithful to the earth," therefore, is anything but easy and comfortable. It is in times of trouble that most test our resolve for the only life we have. 
24 Nietasche on Sickness and Health

Lawrence J. Hatab is Louis I. Jaffe Professor of Philosophy Emeritus at Old Dominion University. He is the author of seven books and numerous articles, mostly on Nietzsche, Heidegger, and ancient thought. His books on Nietzsche are $A$ Nietzschean Defense of Democracy: An Experiment in Postmodern Politics, Nietzsche's Life Sentence: Coming to Terms with Eternal Recurrence, and Nietzsche's On the Genealogy of Morality. His latest work is a two-volume study of language, Dwelling in Speech (Rowman \& Littlefield International). 